\title{
A Vision of Hell: \\ Walter Benjamin's Angelus Novus \\ and the Catastrophe of Progress
}

\author{
PRECIOSA REGINA ANG DE JOYA \\ ATENEO DE MANILA UNIVERSITY, PHILIPPINES
}

\begin{abstract}
Before his untimely death in 1940, the German philosopher Walter Benjamin wrote an essay, entitled "Theses on the Philosophy of History," marking his recovery from the shock of the Hitler-Stalin non-aggression pact. This study reflects on the philosophical and historical significance of this essay, unraveling Benjamin's critique of Marxism as a critique of progress. Progress, which the angel of history sees as a storm coming from paradise, has caused a growing pile of rubble of historical blunders and environmental disasters. This uncritical submission to progress, however, can be seen not only in the blind confidence of the communists and the social democrats towards Marxist teleology, but also in historicism, which reduces the writing of history to a form of disaster: a "heaping up of information" that forgets the memory of "enslaved ancestors," thus losing its "weak, Messianic power."
\end{abstract}

Key terms philosophy, history, Marxism, historicism, phantasmagoria

Budhi: A Journal of Ideas and Culture 18.1 (2014): 18-53. 
In the "Theses on the Philosophy of History," the German philosopher
Walter Benjamin brings to our attention a most peculiar image. Inspired by Paul Klee's ink drawing of the Angelus Norus, he depicts the angel of history in a moment of terror: with his eyes glaring, his mouth open, and his wings spread, the angel is transfixed by the sight of the wreckage piling monstrously at his feet. He would like to stay, "awaken the dead, and make whole what has been smashed," but the force of a storm has got caught in his wings, hurling him forward into the future against his will. This storm, which has caused many historical devastations, is a force that Benjamin claims comes from Paradise, a storm that we know by the name of Progress. ${ }^{1}$

In the wake of technological and nuclear advancements, we have seen the rubble of historical blunders and environmental degradations piling up. The image no longer comes as a shock to us. Progress, which was once believed as a positive force of growth, has proven itself to be no more than a harbinger of disaster and death. And yet, we trudge along this path towards our doom, as though we cannot help ourselves. Are we, like the angel, hurled into the future against our will? If so, is it possible that our only redemption lies in re-living that sense of shock, to be, like the angel, perpetually transfixed, contemplating the horrors of the past?

\section{The Historical Context: The Failure of Marxism}

The "Theses," the last essay Benjamin wrote before his untimely death, was completed in the spring of 1940. The essay itself is known to mark Benjamin's recovery from the shock of the Hitler-Stalin non-aggression pact, which took place in August 1939. Like many of the left-wing German intellectuals of that time, Benjamin had placed his hope on the communists, who were considered the only formidable political

\footnotetext{
1 Walter Benjamin, "Theses on the Philosophy of History," in Illuminations, ed. Hannah Arendt, trans. Harry Zohn (New York: Schocken Books, 1969), 257-58.
} 
opponents against Fascism. ${ }^{2}$ His disappointment, however, did not lead him to despair but to a greater resolve to redeem the Marxist tradition "from the snares in which . . traitors have entrapped [it]."3

For Benjamin, the defeat of Marxism-its inability to offer the world not only a determined and powerful resistance to capitalism but a real, alternative ideology — was due not to helplessness against an impregnable force but to the betrayal of its followers to their own cause. In section 10 of the "Theses," he attributes this betrayal to a "stubborn faith in progress,"4 which led Marxists to believe that a proletarian victory was imminent. This unwavering confidence made them complacent, allowing them to embrace every status quo as a justifiable moment towards the realization of their much-coveted classless society.

Equally guilty of such complacency were the social democrats, whose conformism "attaches not only to its political tactics but to its economic view as well."'5 Benjamin held the social democrats responsible for poisoning the mind of the working class, in making the latter believe that technological development was the "fall of the stream," and that, through labor, it was "moving with the current" and doing the revolutionary cause a great service. This meant that the moderate views of the social democrats were in compliance with the capitalist regime. And the betrayal was such that, in assigning to the working class "the role of the redeemer of future generations," these moderate Marxists had cut "the sinews of its greatest strength." In focusing on technological progress and on the promise of a socialist future, the working class was made to forget "both its hatred and

${ }^{2}$ Rolf Tiedemann, "Historical Materialism or Political Messianism? An Interpretation of the Theses 'On the Concept of History,"' in Benjamin: Philosophy, Aesthetics, History, ed. Gary Smith (Chicago: University of Chicago Press, 1989), 195. Rolf Tiedemann's groundbreaking essay gives an important insight into the historical context of Benjamin's "Theses." He argues that, although Benjamin hardly mentions communism and exclusively addresses the failings of social democracy, the essay is more likely a critique of the former, as it was the only political power that really mattered at that time.

${ }^{3}$ Benjamin, "Theses," 258.

${ }^{4}$ Ibid.

${ }^{5}$ Ibid. 
its spirit of sacrifice," which for Benjamin are nourished not by the image of "liberated grandchildren," but by the memory of "enslaved ancestors." 6

Such economic views would inevitably determine a particular political stand. Given its conception of labor, which "recognizes only the progress in the mastery of exploitation of nature, [but] not the retrogression of society," the social democrats could see only goodness in the efforts of imperialism to increase capitalist accumulation. Aside from believing that progress was inevitable, it saw in imperialism an economic solution that once and for all "would raise the standard of living of the lower classes and reduce conflicts over the distribution of wealth and power."8 Moreover, expansion was seen as a "lifesaver," for it offered a political answer to a national body deeply split into classes and by class struggle, insofar as it served to unite the whole nation in a common interest. As a result of "their stubborn faith in progress," the social democrats became blind to the dangers of imperialism that was driven not by a sincere concern for the entire human species but by bourgeois interests in expanding and exporting power and capital. They could not see how imperialism would necessarily divide people into "master races and slave races, into higher and lower breeds, into colored peoples and white men"9 and eventually lead to a social regression that would culminate in Adolf Hitler's totalitarian movement.

The Soviet communists, on the other hand, were no better. They were also victims of the same obsession for progress because they believed that a socialist society could only be realized "under conditions of greater productivity of labor and a highly developed industry." As a consequence, Joseph Stalin imposed a policy of forced industrialization and compulsory collectivization of agriculture, in the belief that such measures would free

\footnotetext{
${ }^{6}$ Ibid., 260.

7 Ibid., 259.

${ }^{8}$ George Lukács, History and Class Consciousness: Studies in Marxist Dialectics (Cambridge, MA: MIT Press, 1971), 32.

9 Hannah Arendt, The Origins of Totalitarianism (New York: Harcourt, Brace \& Company, 1951), 152.
} 
the country from its backward economy. Unfortunately, it led only to the betrayal of the very people whose interests it had sought to advance. ${ }^{10}$

The problem did not lie simply in a distorted interpretation of Marx's thought. Benjamin sensed an inherent contradiction in Marx's own willingness to sacrifice the proletariat for the advancement of the revolutionary cause. Ronald Beiner explains how Marx, in his essay "The Class Struggle in France," had so much faith in the revolution that progress could easily be perceived even in defeat. As Beiner argues:

The progress of the revolution required the creation of a powerful, united counter-revolution, which would provide the opponent necessary for the ripening of a genuinely revolutionary party. So the revolutionary actors are defeated, but the revolution is carried forward. ${ }^{11}$

Benjamin could not subscribe to this optimism. He empathized with those who were trampled on by this onward march of the revolution. And thus, he comments:

\begin{abstract}
Marx says that revolutions are the locomotive of world history. But perhaps it is quite otherwise. Perhaps revolutions are an attempt by the passengers on this train namely, the human race-to activate the emergency brake."12
\end{abstract}

${ }^{10}$ See Georg von Rauch, A History of Soviet Russia, 5th ed., trans. Peter and Annette Jacobsohn (New York: Frederick A. Praeger Publishers, 1967), 180-83. To free the country from its backward economy, Stalin thought it necessary to deport the landowners (kulaks) who, with their love of land and private property, were regarded as a major obstacle to the communist agenda and were thus exiled, en masse, to the arctic region. The peasants who remained were forced to "cooperative economic units," or kolkhozes, which were obliged to hand excess produce to the state. Stalin's obsession for progress is best demonstrated in his attempt to accelerate the mechanization of agriculture through the mass slaughter of horses. Naturally, without horses, massive areas of agricultural land could only be cultivated with tractors. This method caused an artificial famine that practically made mechanization a matter of life and death.

11 Ronald Beiner, "Walter Benjamin's Philosophy of History," Political Theory 12.3 (August 1984): 425, http://www.jstor.org/stable/191516.

12 Walter Benjamin, "Paralipomena to 'On the Concept of History,"” in Selected Writings, vol. 4, 1938-1940, ed. Howard Eiland and Michael W. Jennings, trans. Edmund Jephcott et al. (Cambridge, MA: The Belknap Press, 2003), 402. 
Finally, Benjamin observed that the Marxists were so confident of their "mass basis"13 that it served the perfect justification for their actions. ${ }^{14}$ Both the social democrats and the communists firmly believed in the altruistic nature of their goals. But the violence that was employed to accomplish these goals obviously made it difficult for anyone to believe that their ideology was indeed mass-based. ${ }^{15}$ This "mass-basis" was nothing but a mere façade that tried to conceal the betrayal that festered within Marxism. Although we cannot deny the liberating spirit and critical force intrinsic to it, Marx's teleology, particularly its belief in the victory of the proletariat, has proven harmful to its own cause. Benjamin believed that as long as Marxism continues to subscribe to such a teleology, it can only be a "science of legitimation," one that merely pays lip service to that "uncontrollable apparatus"16 which we know as Progress.

\section{The Idea of Progress}

Marxism's blind faith in progress was neither a defect particular to its ideology, nor was it a deviation of a specific age from a more enlightened understanding of it. Rather, it was the logical outcome of a long tradition that had always conceived history in terms of a progressive movement. Benjamin's quarrel, however, was not with the idea of progress per se but with a false notion of it, namely, "a conception of progress which did not

\footnotetext{
${ }^{13}$ Benjamin, "Theses," 258.

14 Stalin would stubbornly insist: "No, comrades, the pace must not be slackened! On the contrary, we must quicken it as much as is within our powers and possibilities. This is dictated to us by our obligation to our own workers and peasants, to the working class of the whole world. To slacken the pace would mean to lag behind; and those who lag behind will be beaten." (J. Stalin, Problem of Leninism [Moscow, 1947], 157; quoted in Rauch, History of Soviet Russia, 184).

${ }^{15} \mathrm{We}$ also learn from Arendt that after ridding the state of its property-owning classes, and impelling the Russian worker to forced labor, Stalin executed the very people who helped carry out previous liquidation measures. Furthermore, he outlawed all political labor groups and deviations within the Party, which clearly eliminated any representation of the opposition. See Arendt, Origins of Totalitarianism, 313.

${ }^{16}$ Benjamin, "Theses," 258.
} 
adhere to reality but made dogmatic claims." 17 Benjamin clarifies this problem in one of the fragments found in his unfinished work, The Arcades Project. There, he states:

The concept of progress had run counter to the critical theory of history from the moment it ceased to be applied as a criterion to specific historical developments and instead was required to measure the span between a legendary inception and a legendary end of history. In other words: as soon as it becomes the signature of historical process as a whole, the concept of progress bespeaks an uncritical hypostatization rather than a critical interrogation. ${ }^{18}$

In light of this, a survey of the historical adventure of the idea of progress becomes crucial. By roughly tracing its development in the history of ideas, we hope to better understand how and why progress, once a standard for "critical interrogation," had fallen to the status of an "uncritical hypostatization."

\section{Progress as Secularized Redemption}

The concept of progress plays a crucial role in human history insofar as it constitutes the idea of redemption. Redemption itself is an idea that appears in Christian eschatology and is perceived as the telos or the goal at the end of time. At the end of time awaits the promise of restored harmony, of total freedom and happiness. This utopian totality is implied in the idea of progress insofar as we believe progress to contain the possibility of our salvation.

\footnotetext{
${ }^{17}$ Ibid., 260.

18 Walter Benjamin, "Konvolut N [On the Theory of Knowledge, Theory of Progress]," in The Arcades Project, ed. Rolf Tiedemann, trans. Howard Eiland and Kevin McLaughlin (Cambridge, MA: The Belknap Press, 1999), 478.
} 
The idea of progress, which was already implicit in the Stoic theorem of the universal state and conception of humanity, was later reconciled with Rome's imperial aggressions, and thus evolved into a movement towards the increase of "skills and knowledge."19 Eventually, with St. Augustine's idea of civitas dei, progress was connected "to the redemption by Christ, as the historically successful redemption," which told the story of humanity, saved by divine grace, in its journey "in the continuum of time towards the heavenly kingdom." 20 However, as redemption failed to deliver and eradicate all evil, an "aura of redemption" took its place in a secular appropriation of Augustine's idea of immanent teleology which dispenses with Christian soteriology. Thus, with the coming of the age of Enlightenment, we find the idea of progress finally brought to the civitas terrena, where the redemption of humanity is placed in human hands. ${ }^{21}$

Believing in the powers and the perfectibility of reason, it was then a common belief that the human race, left to itself, would "automatically pursue virtue and knowledge, and the improvement of the world." Failures were caused simply by ignorance and therefore could be corrected through the proper education of the mind to the laws that regulate the behavior of nature. ${ }^{22}$ Such education could only be acquired through a gradual process, which described a series of changes that were perceived not to be arbitrary but characteristic of a movement from good to "better"; where to speak of "better" guarantees not only that a moment emerges as an improvement of its precedent, ${ }^{23}$ but that each instance is always defined as a step "closer" in relation to the clearly envisioned goal.

\footnotetext{
19 Theodor Adorno, "Progress," in Critical Models: Interventions and Catchwords (New York: Columbia University Press, 2005), 146.

20 Ibid.

${ }^{21}$ Ibid.

22 Isaiah Berlin, Karl Marx: His Life and Environment, 4th ed. (Oxford: Oxford University Press, 1996), 28-29.

${ }^{23}$ R. G. Collingwood, The Idea of History, ed. Jan Van Der Dussen (Oxford: Oxford University Press, 1994), 326.
} 
History, therefore, is the journey of reason towards its full "enlightenment," a movement that we came to know as progress. In this way, the role of progress is essential to history: it is the underlying thread that weaves the events of history - which would otherwise be arbitrarycreating a meaningful continuum and a coherent totality.

Insofar as progress is the secularized form of redemption, it embraces not a selected few but the entire human race, as the idea of the divine salvation equally implied. Progress therefore does not merely include equality and fraternity; it is the establishment of equality and fraternity. It is precisely this that Karl Marx's idea of a classless society seeks to achieve: the defeat of capitalism by the proletariat is not the establishment of the latter's tyranny but the abolition of its own class. It is the same totality that Immanuel Kant envisions when he speaks of a moral and political unity through the creation of a universal civic society, where a lawful external relation among states is established in order to ensure security and justice for even the smallest among them. ${ }^{24}$

\section{The Problem of Evil}

What constantly challenges the realization of a heaven-on-earth is the reality of evil. The meaningfulness of history founders in the face of evil, which is an immanent threat to progress. Attempts have been made to make sense of these moments of irrational violence, which Kant in particular reconciles by recognizing the value of conflict.

With Kant, the human burden to develop the capacities of reason and to realize redemption on earth is affirmed: history, as the realm of free will, constantly distinguishes itself from nature by man's progressive realization of his autonomy in and through society. 25 Hence, the final and most

\footnotetext{
${ }^{24}$ Immanuel Kant, "Idea for a Universal History from a Cosmopolitan Point of View," in Kant Selections, ed. Lewis White Beck (New York: Macmillan Publishing Co., 1998), 418-19.

${ }^{25}$ Michel Despland, Kant on History and Religion (Montreal: McGill-Queen's University Press, 1973), 45.
} 
difficult task that Kant assigns to humankind is the establishment of that universal civic society. ${ }^{26}$ Coming close to this goal, however, could only be possible after numerous "inadequate and tentative attempts." ${ }^{27}$ For Kant, it would only be after "devastations, revolutions, and even complete exhaustion" that humanity could establish this universal civic society. ${ }^{28}$

Kant recognizes all of these undertakings as part of the plan of Nature. Although she leaves man to his devices, Nature desires the fulfillment of all capacities of each of her creatures ${ }^{29}$ and thus endows every human heart, from the beginning, with what Kant calls an "unsocial sociability." This "unsocial sociability," which causes antagonism among people, is Nature's way of awakening the powers of reason and its mode of seeking a solution through the creation of social arrangements. The value of conflict for Kant therefore lies not only in the fact that it guides the human race to the path of progress, that is, to the establishment of society out of the necessity of self-preservation. More importantly, conflict itself and its consequences, no matter how irrational they may appear to human reason at first, are a proof that everything happens according to a providential plan and that what "seems complex and chaotic ... may be seen from the standpoint of the human race as a whole," 30 as "the ordering of a wise Creator and not the hand of an evil spirit who bungled in his great work or spoiled it out of envy." 31

\footnotetext{
${ }^{26}$ Kant's universal civic society does not seek only a biological unity of all human races but a political or moral unity as well, where all people become part of a consolidated power "acting according to decisions reached under the laws of their united will." (Kant, "Universal History," 420). This is what it means when we speak of the full 'enlightenment' of reason: it is when the human race becomes its highest master, a body of total self-governing beings, that extends the powers of reason to the limits; not only in mastering nature but in creating institutions and laws that organize and affect every aspect of life and all possible human relation.

${ }^{27}$ Kant, "Universal History," 420.

28 Ibid.

${ }^{29}$ Ibid., 416.

${ }^{30}$ Ibid., 415.

31 Ibid., 418.
} 
The idea of a providential plan guiding history is to be found in G.W.F. Hegel's thought as well. History, which is for him the process by which the Spirit (the Absolute Idea as it develops in Time) knows itself, is nothing but the unfolding of God's nature in a particular determinate element. ${ }^{32}$ But if, indeed, every moment were to be seen as part of the Spirit's selfunderstanding, wouldn't this idea render the wickedness of the ways of men less problematic? Hegel says:

When we see the evil ... the human spirit has created ... we can only end with a feeling of sadness at the transience of everything. . . . There is nothing we can do about it now. . . . Indeed, we retreat into that selfish complacency which stands on the calmer shore and, from a secure position, smugly looks on at the distant spectacle of confusion and wreckage. But even as we look upon history as an altar on which the happiness of nations, the wisdom of states, and the virtue of individuals are slaughtered, our thoughts inevitably impel us to ask: to whom, or to what ultimate end have these monstrous sacrifices been made?33

It is when faced by human evil that reason instructs us that everything, including the tragedies, no matter how monstrous, is part of the strife that comes with the process of the Spirit's self-awareness. Furthermore, Hegel argues that although passions and personal ends are the prime movers of human actions, by the fact that they "produce an effect altogether different from what they themselves intend and accomplish," we know that they serve a higher purpose. ${ }^{34}$ Although personal interests are gratified, they are merely the means the world Spirit employs to attain the universal. While Kant calls this the plan of Nature, Hegel calls it the "ruse of reason," which drives men to act while ignorant of the greater plan. Rationalism

\footnotetext{
${ }^{32}$ G. W. F. Hegel, Lectures on the Philosophy of World History, trans. H. B. Nisbet (New York: Cambridge University Press, 1975), 42.

33 Ibid., 69.

34 Ibid., 75.
} 
attempts to make all things accessible to reason, so much so that the existence of evil, which is now seen merely as a part of Nature's design or the Absolute Spirit's self-understanding, is no longer deemed to be a threat or a setback to human progress.

\section{Progress as Growth}

Equally important to the idea of progress is the concept of growth. In fact, Hegel applies the idea of growth to history by presenting the entire world (natural, historical, and intellectual) as one organic body in a process of constant motion and transformation. ${ }^{35}$ In doing so, he animates every aspect and moment of the Spirit's movement in history with the force of progress. ${ }^{36}$ One has to understand, however, that the Spirit's growth is possible only through a critique that exposes the particularity of its present determinate form, from the standpoint of the world spirit, that is, of world history. Its critique of its own immediate existence consequently leads to divisions within and to the downfall of the nation. ${ }^{37}$ At the same time, however, these divisions contain the very condition for the possibility and necessity of unification, which would require the emergence of a new and higher principle to replace the old one. Simply put, this growth from one principle to a higher and better one, is only possible through a critical selfconsciousness that emancipates the Spirit from the "tyranny of the merely

\footnotetext{
${ }^{35}$ Frederick Engels, Socialism: Utopian and Scientific, in Karl Marx and Frederick Engels: Selected Works in One Volume (New York: International Publishers, 1986), 413.

${ }^{36}$ For Hegel, the spirit's growth in self-awareness becomes possible when it assumes a determinate form in the national spirit at each moment in its development. The national spirit is the world spirit in its mode as ego, an individual thinking atom that "wills only itself and wills itself in everything." (Hegel, Lectures, 78.) Thus, in the act of thinking, it doubles only itself, which basically refers to the entire life of a nation-its industries, customs, religion, system of justice, political and social institutions, etc. The role of the national spirit, however, only becomes meaningful when it is understood, in its particularity, as the antithesis (posited by the world spirit itself in the activity of being self-conscious) to the world spirit in its universal essence. It is the task of this ego, made possible after creating its double, to reflect and gain knowledge of its function. The object of self-knowledge is for the national spirit to realize its particularity in relation to the world spirit, that is, to the totality of world history to which it belongs.

${ }^{37}$ Hegel, Lectures, 61.
} 
actual," that is, from "obstructive and useless institutions" that prove inadequate to its historic role, and from the indolence of people ${ }^{38}$ who lie back and permit the status quo to justify its place and perpetuate its rule even after it has outlived its purpose and function in history.

Another important aspect of growth in Hegel's concept of history is the dialectical concept of preservation (Aufhebung). The world Spirit, which recognizes the particularity and the fleeting nature of its present life through critical self-reflection, discovers the universal and enduring aspect or essence of its former existence as well. It is this that makes the passage of the world Spirit from one national spirit to the next a kind of growth different from the simple "re-awakening of nature." Passage does not simply mean the obliteration and replacement of a previous form. Rather, every form that the Spirit assumes is preserved in "the self-conscious activity of the self-consciousness." ${ }^{39}$ This preservation (Aufhebung), which is both conservation and a transfiguration, is what allows the Spirit to assume a higher form and not simply a different one. Thus, the growth of the spirit is not merely a repetition of the same life cycle as in Nature but a "movement and progress [that] do not repeat themselves." 40 In this way, the idea of growth in Hegel's philosophy of history shows not only the importance of critical activity that brings progress, but also defines each moment in its movement as always new and unique.

\section{The Illusion of Progress}

It is the ill fortune of ideas to lose their more potent and inspiring elements over time. Such is the case with the idea of progress, which, according to Benjamin, no longer adhered to reality and instead made dogmatic claims. Hegel, with his concept of history grounded on the idea of growth, had justified the perfection of each present moment-as it was

\footnotetext{
${ }^{38}$ Berlin, Karl Marx, 49.

${ }^{39}$ Hegel, Lectures, 61.

${ }^{40}$ Hegel, Philosophy of World History, 61.
} 
not only the metaphysical unfolding of the Idea at a given moment in time, but historically the synthesis of its predecessors and thus, the culmination of what has been achieved so far. Consequently, this rendered every status quo an inevitable and necessary stage in the Spirit's development. Taking Hegel's ideas further, the conservative young Hegelians thought it appropriate to conclude the infallibility of the present: that the real, being necessary, is not only impossible to conceive as evil but also to alter it would be futile and morally wrong. ${ }^{41}$

The final congealment of the idea of progress into dogma takes place with the application to history of the Darwinian concept of evolution. The doctrine of the survival of the fittest proved Hegel wrong, even as it radicalized the Hegelian idea in the realm of nature: history and nature are not so different after all, the latter having a progressive and unique movement of its own. This affirms even more the idea that history's own progressive movement is natural and automatic. ${ }^{42}$ If in Kant there is still the recognition of a possible regression, Hegelianism and Darwinism together render this possibility unimaginable.

Stripped of its critical power, the idea of progress became the greatest ally of the nineteenth-century bourgeoisie. The bourgeoisie, who at one moment in history rallied with the people against feudalism and aspired for equality and fraternity, lost its critical spirit once it held positions of power, now concerning itself solely with the justification and perpetuation of its rule. When the bourgeois society "could not realize its own reason, its own ideal of freedom . . . without its order being sublated,"43 it desperately created an illusion of progress to convince everyone of the validity of its rule. First, it persuaded people to see bourgeois society and its capitalist economy as the embodiment of true human nature and of a growth based on the survival of the fittest characteristic of natural history. Among the bourgeoisie were Social Darwinists who sought to defend

\footnotetext{
${ }^{41}$ Berlin, Karl Marx, 48.

42 Collingwood, Idea of History, 131.

43 Adorno, "Progress," 154.
} 
the social status quo by claiming that competitive capitalism expressed true human "nature," that imperialist rivalries were the healthy result of an inevitable struggle for survival, and that the ruling "races" were justified as the dominators on the basis of "natural" superiority. Within this pseudoscientific discourse, the claim of social injustice became a logical impossibility. ${ }^{44}$

This was the argument presented to justify imperialism, which, stripped of its hypocrisy, was nothing but the exportation of unlimited, corrupt power for the purpose of allowing and protecting the interests of colonizers in their quest for the unlimited acquisition of wealth. ${ }^{45}$

Ideological justifications, however, proved insufficient. "Sociologically," the bourgeoisie had to "eradicate the fact of class conflict from the consciousness of society." 46 They created a semblance of development, as well as an illusion of political democracy and social equality, to establish a phantasmagoria of progress. ${ }^{47}$ It was clear that the bourgeoisie was too rooted in property relations to allow the "socialised character of the means of production complete freedom to work itself out."48 Their personal agenda already placed a decisive stamp on the reception of technology, the

${ }^{44}$ Susan Buck-Morss, The Dialectics of Seeing: Walter Benjamin and the Arcades Project (Cambridge, MA: MIT Press, 1993), 58-59.

${ }^{45}$ Arendt, Origins of Totalitarianism, 143.

${ }^{46}$ Lukács, History and Class Consciousness, 61-62.

47 Buck-Morss explains how phantasmagoria transforms the idea of progress into a commodity, which is no longer important for its use value but significant as a spectacle, that is, for its representational purposes. She refers to the world expositions of nineteenth-century Europe, which displayed the latest technological devices as a spectacle for "mass entertainment," targeting the working class as its primary audience. Further, she explains that the proletarians were encouraged to "make the pilgrimage to these shrines of industry, to view on display the wonders that their own class had produced but could not afford to own, or to marvel at machines that would displace them." The goal was to show the working class not only of society's progressive development but to convince them of their determined role in the present social structure. (BuckMorss, Dialectics of Seeing, 86). See also Walter Benjamin, "Paris, the Capital of the Nineteenth Century: Exposé of 1935," in The Arcades Project, 7.

${ }^{48}$ Engels, Socialism, 432. 
role of which was perceived "solely for the production of commodities." 49 The goal of technology was therefore directed towards the accumulation of wealth, and progress had become linked to the development of "knowledge pure and simple" ${ }^{50}$ which was essential to the improvement of technologies towards greater efficiency and productivity. Such a conception of progress was thus no more than the expression of a particular relation where man exercises mastery and domination over nature.

For as long as this is the case, equality and fraternity cannot be delivered as promised, and the idea of totality, of progress for all humankind, is no more than a myth. The bourgeois concept of humankind, though it claimed to be universal, was merely "both totalitarian and particular." Though it may have granted happiness to a few, it perpetually denied those who had been excluded from attaining any joy. And so, quoting Hermann Lotze, Benjamin inquires, how indeed "upon such assumptions can we be entitled to speak of one history of mankind?" How can we speak of a totality in progressive movement, when we see only a small minority moving to greater heights while "the mass of mankind remains mired in an uncivilized condition?"51

\section{Catastrophe}

Although bourgeois society rallied behind the idea of progress, the concept was clearly bereft of any redemptive value and was used merely for show. This conception of progress, which no longer adhered to reality, was what Benjamin described as an "uncritical hypostatization." What once offered a critical standard had now become a reified commodity that wielded an autonomous existence that was both antagonistic and alienating to its human creator. Indeed, it was an idea of progress that "not only did

\footnotetext{
${ }^{49}$ Walter Benjamin, "Eduard Fuchs: Collector and Historian," in One-Way Street and Other Writings, trans. Edmund Jephcott and Kingsley Shorter (London: NLB, 1979), 358.

50 Ibid., 357.

51 Benjamin, "Konvolut N," 480.
} 
not want the liberty and autonomy of man, but was ready to sacrifice everything and everybody to supposedly superhuman laws of history." 52

\section{The Rebellion of Technology}

With progress conceived as the growth of "knowledge pure and simple," aimed at creating more efficient means of production for the accumulation of wealth, technology has left humanity feeling lost and vulnerable, despite the tremendous power and knowledge it gives. Marx has already given us an account of human alienation in old, industrial capitalist society, where machinery that is supposed to reduce labor time and make work easier is used by capitalism to extend the hours of work and increase the intensity of production. With the rise in the value of things, brought by an obsession for accumulated wealth, the person is reduced simply to a means toward the production of commodities. In fact, the person himself becomes a commodity, employed and measured according to his usefulness and efficiency.

For Benjamin, however, capitalism was still at its infancy at the time of Marx's critique. It is only recently that we are able to experience the fruition of its horrific nature and how radically it has transformed the superstructure. ${ }^{53}$ Historically, we realize that one of the most catastrophic consequences of technological development lies in the creation of increasingly efficient means of warfare. Using its own invention not only for the disintegration of the human aura ${ }^{54}$ but, this time, for its abolition,

\footnotetext{
52 Arendt, Origins of Totalitarianism, 143.

${ }^{53}$ Walter Benjamin, "The Work of Art in the Age of Mechanical Reproduction," in Illuminations, 217.

${ }^{54}$ In "Work of Art," Benjamin defines "aura" as "the unique phenomenon of a distance" (222), and "that which withers away in the age of mechanical reproduction" (221). The capacity of technical productions to produce copies of the original have enabled the latter to exist in situations and places that may otherwise be impossible for it to reach. At the same time, the quality of its presence is diminished. This, however, has consequences not only for art but for society as well. We see the decay of the aura not only in the desire of the contemporary masses "to bring things 'closer' spatially and humanly" (223), but in its most terrifying form, in the creation of technologies and war, where human life becomes completely superfluous and self-alienation is a form of destruction experienced as an aesthetic pleasure.
} 
humanity reaches a level of alienation never before imagined. In this case, alienation is no longer a matter of reducing man to the state of a beast, where the dignity of work is devalued into a means for survival. Here, the complete reification of the human aura is achieved: human life itself completely assumes the life of the commodity, particularly its superfluous nature. As commodities in excess lose their value, human lives, in the age of the masses, become senseless and superfluous in an overcrowded world. ${ }^{55}$ Here, humanity plummets to a level of existence even lower than the animal; for once it seeks to improve weapons for the purpose of the destruction of its own kind, it reflects the loss of the natural instinct for life and self-preservation. ${ }^{56}$

In addition to this perversion is the fact that technology has also become a tool by which the masses are taught to experience "its own destruction as an aesthetic pleasure of the first order." 57 Through film shots of "big tanks, the geometrical formation flights, [and] the smoke spirals from burning villages," war could now be seen as a newly found form of architecture, or a symphony that "combines the gunfire, the cannonades, the cease-fire, the scents, and the stench of putrefaction." 58 War, that once was considered anti-aesthetic, now proves itself to be a spectacle equally beautiful, for it not only “establishes man's dominion over the subjugated machinery" through gas masks and what not, but also "initiates the dreamt-of metallization of the human body." 59 In this way, technology is utilized not only to produce weapons but as a means of propaganda to "prepare public opinion for war."60

\footnotetext{
55 Arendt, Origins of Totalitarianism, 431.

${ }_{56}$ Walter Benjamin, "One-way Street," in Reflections: Essays, Aphorisms, Autobiographical Writings, ed. Peter Demetz, trans. Edmund Jephcott (New York: Schocken Books, 1978), 71-72.

${ }^{57}$ Benjamin, "Work of Art," 242.

${ }^{58}$ Ibid., 241.

59 This is a quote from Marinetti. The source is unknown. (Benjamin, "Work of Art," 24142.)

${ }^{60}$ Benjamin, "Eduard Fuchs," 358.
} 
Benjamin is here the angel of history who gives us an urgent warning: for as long as we continue to give capitalism full power to determine the means of production, technology will never realize an adequate actualization of its powers; and "the increase in technical devices, in speed, and in the sources of energy will press for an unnatural utilization." ${ }^{61}$ For as long as technology is used for the accumulation of wealth, and consequently, in the struggle of all against all, it will never realize its true, social character. Instead, it will constantly lead us to a state of war. As Benjamin explains:

Imperialistic war is a rebellion of technology which collects, in the form of "human material," the claims to which society has denied its natural material. Instead of draining rivers, society directs a human stream into a bed of trenches; instead of dropping seeds from airplanes, it drops incendiary bombs over cities; and through gas warfare the aura is abolished in a new way. ${ }^{62}$

\section{Caught in an Eternally Recurring Hell}

For Benjamin, however, war is not the ultimate catastrophe. To bungle is inherent to our nature and human action is essentially unpredictable, insofar as it is impossible to tell what a deed, which never fulfills its original intention, will finally accomplish. Such is the "melancholic haphazardness" of human action with which we must learn to deal. ${ }^{63}$ Nevertheless, to repeat the same foolishness would be an inexcusable failing. At present, humanity seems to be persistently caught in a state of war, such that we have come to accept, as Jean-Luc Nancy argues, that our time is a time when

\footnotetext{
${ }^{61}$ Benjamin, "Work of Art," 242.

62 Ibid.

${ }^{63}$ Hannah Arendt, "The Concept of History," in Between Past and Future: Eight Exercises in Political Thought (New York: Penguin Books, 1977), 84-85.
} 
History is suspended, or even finished, as sense, as the directional and teleological path that it has been considered to be since the beginning of modern historical thinking. History no longer has a goal or a purpose. . . . [It] can no longer be presented as-to use Lyotard's term, a "grand narrative," the narrative of some grand, collective destiny of mankind (of Humanity, of Liberty, etc), a narrative that was grand because it was great, and that was great because its ultimate destination was considered good. Our time is the time, or $a$ time ... [of] total war, genocide, the challenge of nuclear powers, implacable technology, hunger, and absolute misery, .. . [which are], at the least, evident signs of selfdestroying mankind, of self-annihilatory history, without any possibility of the dialectic work of the negative. ${ }^{64}$

It is evident that humanity has not been learning from history, and, like in the myth of Sisyphus, it finds itself caught in a time of hell, which Benjamin describes is "not something that awaits us, but this life here and now."'65 It is therefore the status quo in which we find ourselves entrapped.

Drawing from the ideas of Auguste Blanqui's L'Éternité par les astres, Benjamin identifies this time of hell as a world entangled in myth. A world caught in phantasmagoria is a world entranced by the spectacle of its own wishes and desires that have been forbidden to exist in the present life. ${ }^{66}$ Here, "humanity figures . . . as damned. Everything new it could hope for turns out to be a reality that has always been present." 67 Such is the idea of

\footnotetext{
${ }^{64}$ Jean-Luc Nancy, "Finite History," in Birth to Presence, trans. Brian Holmes (California: Stanford University Press, 1993), $144-45$.

${ }^{65}$ Benjamin, "Konvolut N," 473.

${ }^{66}$ H. D. Kittsteiner, Jonathan Monroe, and Irving Wohlfarth, "Walter Benjamin's Historicism," New German Critique 39, Second Special Issue on Walter Benjamin (Autumn 1986): 198, http://www.jstor.org/stable/488125. Kittsteiner describes the phantasmagoric phenomenon or "phantasms" as "libinal representations that have been rejected by the system of culture and forced into the unconscious, where they do not, however, disappear but rather continue to press for the fulfillment of their wishes" as they enter the world of capitalist commodities.

${ }^{67}$ Benjamin, "Paris," 15.
} 
eternal recurrence, ${ }^{68}$ where hell's punishment, once "an eternity of torment," has now become "an endless, arduous cycle." 69

It is because of this endless repetition that we can no longer believe "in history as being the 'ruse of reason,' the ruse by which reason would make the rose of ultimate, rational truth bloom."70 We lament the fact that our time no longer represents "a time that makes history," and that history, determined by the force of causality, has merely become "the unending production of effects" in the course of which we remain helpless. ${ }^{71}$ Furthermore, it is an infinite series of effects that is essentially the return of the same, of what has always been present. It is indeed the deplorable state of a world where phantasmagoria constantly ensures that nothing finds fulfillment. We can thus be certain that the series of effects we experience in our time is never the unraveling of the "effectivity of a beginning." " There is no longer any event that we can consider "historic," in the sense that it "inaugurates" the truly new. Thus, eternal recurrence performs what the philosopher Maurice Blanchot calls "the interruption of the incessant," 73 which refers not to the disruption that halts the continuous, but to "the break which the uninterrupted, the unbroken, is." 74 Eternal recurrence is itself "that which has put a stop to every arrival," 75 the incessant that brings history to an indefinite suspension.

${ }^{68}$ Benjamin further explains the idea of eternal recurrence by quoting an important passage from Blanqui's work. Here, Blanqui explains the idea of a present "eternalized": "What I write at this moment in a cell of the Fort du Taureau I have written and shall write throughout all eternity — at a table, with a pen, clothed as I am now, in circumstances like these." The eternity of the present is achieved by the latter's infinite repetition of itself. From this, we conclude that indeed, "there is no progress." (Benjamin, "Paris," 18.)

${ }^{69}$ Benjamin, "Paralipomena," 403. Quoting the French poet Paul Eluard (Répétitions, 1922) Benjamin identifies eternal recurrence as "the punishment of being held back in school, projected onto the cosmic sphere: humanity has to copy out its text in endless repetitions." He further explains that, in the nineteenth century, this "mythic doom" of eternal recurrence is carried out by Friedrich Nietzsche. (Benjamin, "Paralipomena," 404).

${ }^{70}$ Nancy, "Finite History," 145.

${ }^{71}$ Ibid., 146.

72 Ibid., 145.

${ }^{73}$ Maurice Blanchot, The Writing of the Disaster, trans. Ann Smock (Lincoln: University of Nebraska Press, 1995), 21.

${ }^{74}$ Ibid., ix.

${ }^{75}$ Ibid., 1. 


\section{The Problem of Historicism}

What is it that keeps us from putting an end to this infinite return? Are we, like the angel, helpless against the march of time? Is it simply our fate to suffer the disaster that we have caused in our reckless flight? Here, we return to the problem of progress, to explore further how this phantasmagoric phenomenon has graver consequences for thought, particularly in leading to a historiography that perpetuates the time of hell.

With the phantasmagoria of progress, we realize that Lukács was right not only in identifying commodity fetishism as the "specific problem of our age," but that commodification pervades not only the realm of economics but the superstructure as well. ${ }^{76}$ Progress, transformed to a spectacle, however, does not merely refer to a commodity that wields an autonomous and alienating force. Its reification signals a more profound disaster: that of the betrayal of language, which is seen in how words have lost their immediacy to truth $^{77}$ and have become a part of the mechanism of oppression.

This betrayal, as we have demonstrated above, is evident in the conception of progress reified to an ideology. Here, the idea of progress fosters a certain complacency that leads to blindness to social regression as well as an inability to avert disaster. But we can further argue that the belief in a suprahuman force reduces history itself to a phantasmagoric phenomenon. History that no longer permits the existence of freedom and instead appears to be deterministic ${ }^{78}$ is history reduced to a mere spectacle; for despite modernity's faith in reason, its evolutionary view of history

${ }^{76}$ Lukács, History and Class Consciousness, 83-84.

77 Timothy Bewes, Reification or the Anxiety of Late Capitalism (London: Verso, 2002), 4. Bewes offers a religious interpretation to the concept of reification, by linking it to the Fall of Adam which marked humanity's separation from truth. Furthermore, he describes reification as "what happens when the hubris of the Tower of Babel is punished by the fragmentation of human speech into the languages of the world, thereby cutting off the realm of words forever from that of things." The loss of the immediacy of language is an idea that is clearly present in Benjamin's earlier works.

78 See Benjamin, "Eduard Fuchs,” 369. 
would not allow human freedom to direct or at the very least have a share in its own course. Historical movement has been witnessed, for the most part, as something "beyond human effort," guided by a transcendent power that "could only be obeyed or disobeyed."79

In the "Theses," however, Benjamin is far more concerned about another view of history, namely, historicism. He allocates the first few fragments of his essay to a critique of this particular historiography, but the relation of historicism to the idea of progress as catastrophe is hardly explicated, leaving it to the reader to make the necessary connections. We can only dare to make a conjecture that, in Benjamin's view, historicism was also entangled in the myth of progress, though in a less conspicuous manner, namely as a manifestation of how the force of progress adversely transforms language, particularly in its written form.

H. D. Kittsteiner explains that historicism appeared in the middle of the nineteenth-century as an approach to history that rivaled that of historical materialism. Both traditions were a reaction to the evolutionary view of the classical German philosophy of history. But what historicism critiqued was the latter's inability to value every epoch on equal terms. As the historicist Leopold von Ranke argues:

Should one want to suppose ... that progress resides in the higher potentiality of each age in the life of man, that each generation completely surpasses the preceding one, and that the latter is inevitably the most privileged, the previous ones being only the bearers of those that succeed them, this would be an injustice on God's part. Such, as it were, mediated generations would have no meaning in and of themselves; they would only have meaning as a stage preparing the way for the following generations and would not stand in an immediate relation to the divine. ${ }^{80}$

\footnotetext{
${ }^{79}$ Arendt, Origins of Totalitarianism, 435.

${ }^{80}$ Leopold von Ranke, Über die Epochen der neueren Geschichte (Darmstadt, 1965), 8; quoted in Kittsteiner et al., "Benjamin's Historicism," 180-81.
} 
The goal of historicism was therefore to make each era "immediate before God." To accomplish this, the historian must preserve the specificity of the age, and redeem it from a certain politicization that uses the past, as it were, for the benefit of the present and of the future. Thus, the goal is simply to present history, in the words of the historicists, "the way it really was." 81

Benjamin's contention against historicism is directed precisely at this goal. It was precisely its lack of politicization that Benjamin wanted to correct and restore. ${ }^{82}$ But one wonders: What is so wrong with this "calm, contemplative attitude" 83 which the historicists assumed?

First of all, Benjamin reveals to us the absurdity of the historicist's task. In a fragment, he quotes Grillparzar who argues:

To read into the future is difficult, but to see purely into the past is more difficult still. I say purely, that is, without involving in this retrospective glance anything that has taken place in the meantime. The "purity" of the gaze is not just difficult but impossible to attain. ${ }^{84}$

Benjamin's contention against the "purity' of the gaze" lies in the fact that this way of presenting the past does not allow any involvement with the present, not just in terms of denying the prejudices that play in an epoch's understanding of what has been, but in forbidding the past from being seen as a true concern for the present generation. But in what sense does the past fail to be relevant?

In a fragment found in The Arcades Project, Benjamin argues that the view of history that showed things "as they really were," was indeed "the strongest narcotic of the century." 85 Such presentation lulls us to sleep by

\footnotetext{
${ }^{81}$ Benjamin, “Theses,” 255.

${ }^{82}$ Kittsteiner, "Benjamin's Historicism," 180.

${ }^{83}$ Benjamin, "Eduard Fuchs," 351.

${ }^{84}$ Benjamin, "Konvolut N,” 470.

${ }^{85}$ Ibid., 463.
} 
deluding us into thinking that the past is a "timeless truth," 86 which not only promises to remain the same for all eternity but that which "will not escape us." ${ }^{87}$ And thus, it is with calm contemplation that the historicist gazes upon the past.

The belief in the timelessness of truth, however, only prevails in reducing the past to an object that can be seized by the mind. In doing so, historicism reifies the past into a commodity, 88 in assuming the form of knowledge, which Benjamin describes as characteristically a possession of consciousness. ${ }^{89}$ As knowledge, the past is seen as an event of the past, as something that is "over and done with." ${ }^{0}$ It is "finished" in the sense that its signification is completely and absolutely determined at the time of its occurrence. But we can also say that, for historicism, a historical event is "finished" even before it actually came into existence. If we say that historicism insists on presenting the past as it occurred, it is bound to discover that, in describing what took place, it must justify its conjecture by explaining why it happened. It is in the inquiry of the "why" that the historicist is able to prove that his reconstruction of the past is reasonably what "more or less" took place. The consequence in answering this "why" is that historicism would have to perceive history as a series of effects. That way, an event is already "finished" in the sense that it is an effect already determined by a particular mode of causality. It is all the more "finished" because the meaning of an event, even before it actually exists, is solely defined as "effect."

This is the reason why Nancy calls the time of historicism a time of predetermination. It is "a kind of para-Hegelianism or para-Marxism" that, while no longer subscribing to a suprahistorical power, substitutes the

\footnotetext{
${ }^{86}$ Ibid.

87 Ibid.

${ }^{88}$ Benjamin, "Eduard Fuchs," 360.

89 Ibid., 357.

${ }^{90}$ Ibid., 360.

${ }^{91}$ Nancy, "Finite History," 146.
} 
law of causality as the force that guides the movement of history. As such, the past is significant only to the curious mind as information, but is never truly relevant to the concerns of the present; for as an event that is "finished," the past, as Nancy argues, is "unable to open itself to any future ... , and unable to determine any historical present." 92

The degeneration of history "into the heaping up of information" 93 has led to the reification of the past into what Benjamin calls "cultural treasures."94 This process of enshrinement, he argues, "seeks the establishment of a continuity." 95 But, we ask, a continuity of what sort? It must be obvious at this point that this continuity refers to the historicist's narrative, which constitutes a coherent succession of events. But one can further argue that such a presentation, despite the historicist's claim to pure objectivity, is complicit with the oppressors of history.

Benjamin identifies this complicity as a certain "empathy with the victor." 96 In establishing a succession of events, what would naturally be important for the historicist are those who emerge victorious in history. "Success" therefore functioned as a criterion in the process of elimination that weeded out what the historicist believed was insignificant and what did not fit the logic of the narrative. This is why Benjamin perceived "official history" as a "document of barbarism." 98 As a narrative, it is a continuity that renders history as "a process of silencing." 99 As Shoshana Felman argues:

\footnotetext{
${ }^{92}$ Ibid.

${ }^{93}$ Walter Benjamin, “The Life of Students," in Selected Writings, vol. 1, 1913-1926, ed. Marcus Bullock and Michael W. Jennings (Cambridge, MA: The Belknap Press, 1996), 43.

${ }^{94}$ Benjamin, "Theses," 256.

95 Benjamin, "Konvolut N," 474.

${ }^{96}$ Benjamin, "Theses," 256.

${ }^{97}$ See Hans-Georg Gadamer, Truth and Method, 2nd ed., trans. Joel Weinsheimer and Donald G. Marshall (New York: Continuum, 1999), 203, 215. Gadamer makes a similar argument against historicism.

${ }^{98}$ Benjamin, "Theses," 256.

${ }^{99}$ Shoshana Felman, "Benjamin’s Silence," Critical Inquiry 25. 2 (Winter, 1999): 213.
} 
Because official history is based on the perspective of the victor, the voice with which it speaks authoritatively is deafening; it makes us unaware of the fact that there remains in history a claim, a discourse that we do not hear. And in relation to this act of deafening, the rulers of the moment are the heirs of the rulers of the past. History transmits, ironically enough, a legacy of deafness in which historicists unwittingly share. ${ }^{100}$

Felman is here insinuating that there is "a double silence." On the one hand, official history parades its "cultural treasures" with a loudness that deafens the voices of the minority and silences the tradition of the oppressed. On the other hand, it is a loudness that renders historiography deaf, and therefore silent about the injustices. ${ }^{101}$ What is most catastrophic of all, as Felman argues, is that this form of history is a "legacy of deafness" that transmits itself, making all present rulers "the heirs of those who conquered before them."102 The continuity established by official history therefore seeks only one thing-to preserve the status quo. ${ }^{103}$

\section{A Phantasmagoria of History}

How do we further understand the gravity of this oppression? In what way does historicism help the enemy in preserving the status quo? On the one hand, Benjamin explains that history, in the form of "cultural treasures," "represents for consciousness the category of possession, exactly as capital represents for economics the control of past labour."104

${ }^{100}$ Ibid., 210.

101 Ibid., 213.

${ }^{102}$ Benjamin, "Theses," 256.

103 See Benjamin, "Konvolut N," 474. Benjamin mentions in this fragment that what he considers the "critical moment" is a moment when the "status quo threatens to be preserved." And we should be aware of the "state of emergency" we are in, as the enemy "has not ceased to be victorious." (Benjamin, "Theses," 255).

${ }^{104}$ Benjamin, "Eduard Fuchs," 358. 
History as "capital" is history that has become a tool that allows the rulers to continually have control over the vanquished. The oppressors use this "enshrined heritage" 105 as the stock from which it obtains the myths necessary to strengthen their ideology. ${ }^{106}$ And they evoke the images of the past in order to establish their rootedness in tradition and the authority of their rule.

The catastrophe caused by the historicist's view of history is, however, far greater. And we are not simply referring here to an official narrative that silences the voices of the oppressed, or a continuity that levels off the "peaks and crags" of history where historical, revolutionary action breaks away from tradition. ${ }^{107}$ Neither are we simply alluding to a writing of history that is silent about injustice. In fact, for Benjamin, these are not mainly the problem. He claims that what is problematic is not that the past is forgotten or scoffed. Rather, the catastrophe lies in disseminating them as enshrined heritage," 108 which means that the past is reified into knowledge and "caught in a determinate mode of its existence."109 Consequently, to address the problem of history, it will neither be sufficient to simply acknowledge the injustices nor to remember and give voice to those who have been silenced in the past; for such efforts can also transform into another form of "enshrined heritage," even if it calls itself the revolutionary tradition of the oppressed. Rather, the study of history must be, for every generation, a constant attempt at wresting tradition from the conformism that perpetually threatens it. ${ }^{110}$

\footnotetext{
105 Benjamin, "Konvolut N," 473.

106 Benjamin, "Eduard Fuchs," 357.

${ }^{107}$ Benjamin, "Konvolut N," 474.

108 Ibid., 473.

${ }^{109}$ Giorgio Agamben, "Language and History: Linguistic and Historical Categories in Benjamin's Thought," in Potentialities: Collected Essays in Philosophy, ed. Daniel Heller-Roazen (Stanford: Stanford University Press, 1999), 60.

${ }^{110}$ Benjamin, "Theses," 255.
} 
This conformism does not only allude to the threat that makes history a tool of the oppressors, but also to the force inherent in writing itself. It is a force that commits the past to the "heaviness" of the word, weighing it down and holding it captive, as it were. This of course refers to the conformism that knowledge is, that levels everything into "fact," into a mere commodity of the mind. But then we ask, what is the danger that such conformity brings?

Here, we turn to Plato who, in the Phaedrus, already warns us about the suspicious character of writing. He narrates the story of Theuth who exhibits his newest invention to the Egyptian king, Thamus. This invention refers to no other than writing itself, which he describes as "a potion for memory and for wisdom." Thamus, however, retorts that the effect of writing will be, in truth, the exact opposite of what it claims. And so, Thamus argues:

[Writing] will introduce forgetfulness into the soul of those who learn it: they will not practice using their memory because they will put their trust in writing, which is external and depends on the signs that belong to others, instead of trying to remember from the inside, completely on their own. You have not discovered a potion for remembering, but for reminding; you provide your students with the appearance of wisdom, not with its reality. Your invention will enable them to hear many things without being properly taught, and they will imagine that they have come to know much while for the most part they will know nothing. And they will be difficult to get along with, since they will merely appear to be wise instead of really being so. ${ }^{111}$

Hence, we must be wary of the written language as it is bound to lead us to forgetting.

${ }^{111}$ Plato, Phaedrus, trans. Alexander Nehamas and Paul Woodruff, in Plato: Complete Works, ed. John M. Cooper (Indianapolis, IN: Hackett Publishing Co., Inc., 1997), 275a-b. 
However, it is doubtful that Benjamin simply preferred speech over written language, as we find in Plato. He is, in this way, closer to Blanchot, who identifies the decadence of writing not in all of its instances but specifically in its relation to knowledge. In the Writing of the Disaster, Blanchot, quoting Nietzsche, talks about a "suffering that we bear for 'knowledge's sake."'112 Here, knowledge is referred to as the disaster that "ruins books and wrecks language." 113 It is the phenomenon that brings to existence and constitutes what Blanchot calls "the writing of the disaster," which does not mean a writing that recounts a disastrous event but the writing performed by the disaster itself. Such form of writing not only exemplifies but also carries out the disaster that is the betrayal of language. It is thus a form of writing where language fails to reveal the truth, and instead "carries us, carries us off, deports us ... straight to ignorance and puts us face to face with ignorance of the unknown so that we forget, endlessly."114 Here, the character of knowledge is such that, in filling our heads with a mass of data, it makes us imagine that we know much when in truth we know nothing. And this is perhaps what is most frightening: that the disaster conceals itself by exiling us to ignorance, making us ignorant of the disaster itself. The consequence is that this ignorance allows the disaster to be left undisturbed, so that it may remain for an indefinite time.

But what of this truth that knowledge fails to reveal? What is it precisely that we forget in this writing of the disaster? Here, we return to Benjamin who complains that historicism has made history "nothing but the residue of memorable things and events that never broke the surface of human consciousness because they were never truly, that is politically, experienced." 115 Consequently, its study of the past, which is essentially a

\footnotetext{
112 Blanchot, Writing of the Disaster, 3 .

113 Ibid., ix.

114 Ibid., 3.

115 Benjamin, "Eduard Fuchs," 360.
} 
mere collection of "facts," succeeds only in creating what Benjamin calls a "false aliveness of the past-made-present."116 And this, according to him, only demonstrates that "every vestige of history's original role as remembrance" has been eradicated. ${ }^{117}$

It is indeed quite ironic that the more historicism desired to be faithful to the eternal image of the past, to "remember" and "experience" the past "the way it really was," the more it failed to do so. Its insistence on facts did not help us to remember, but instead, taught us to forget. And here is where the real problem lies: that "facts" do not make our blood boil; the past is an event of the past, it is "over and done with." We can therefore conclude that historicism's greatest disaster is that it used writing to effectively cut "the sinews" of our greatest strength — a strength that feeds on the anger and suffering that can only be evoked not by disinterestedly contemplating the succession of past events but by remembering the image of our enslaved ancestors. ${ }^{118}$

But this is not all that is forgotten. With the inability to remember, not only are we blind to the past, but we also become oblivious to the present. But what of the present? In "The Life of Students," Benjamin warns us of "a view of history that puts its faith in the infinite extent of time." 119 Such a view is merely concerned with the speed at which we advance along this "path of progress," that it critically fails to make demands upon the present. ${ }^{120}$ This failure to challenge the present is due to the fact that time, seen as an infinite progression, fosters an indefatigable patience and tolerance for how things are, and how things turn out to be. And here lies Benjamin's contention against the social democrats: By interpreting the goal of classless society as an "infinite task," social democracy transforms

\footnotetext{
${ }^{116}$ Benjamin, "Paralipomena," 401.

117 Ibid.

118 Benjamin, "Theses,” 260.

${ }^{119}$ Benjamin, "Life of Students," 37.

120 Ibid.
} 
time into an "anteroom . . . in which one could wait for the emergence of the revolutionary situation with more or less equanimity."121

The same is true for historicism, which, however, does not even anticipate the promise of a classless society but perceives time as an "infinite task." It is, in this sense, far worse than social democracy, for at least the Marxists still possessed a standard of how things should be. Historicism, on the other hand, regards things as they are, seeing time no more than as a "quantifiable continuum" filled by events perceived as "quantifiable things."122 It is, of course, quite logical that if the past exists for us merely as "fact," and thus perceived to be already "finished," then there is really nothing for us to do except perhaps to chronicle events as they come. There is, therefore, no task, which is what we mean by a demand made on the present. Hence, what we fail to remember, in forgetting the memory of our enslaved ancestors, is the injustice that had made their lives miserable. But to forget that injustice, to be oblivious to the lamentations of the past, is clearly a form of disrespect for, a betrayal of the memory of their suffering. Thus, in allowing ourselves to be distracted by the succession of events that the historicist parades before us, we neglect an important truth: that in our failure to remember, we allow our time to be a mere continuation of the barbarity of the past.

What is alarming is that this continuity with the barbarity of the past is a continuity that conceals itself as such. It is a continuity that does not see itself as the establishment of an oppressive tradition but only as a description of the infinite progression of time. Continuity conceals the true nature of time as a relation and instead reduces it to a measurable object, by relegating it to the profane dimension of space. But it is also true that

${ }^{121}$ Benjamin, "Paralipomena," 402. Benjamin believed that it was indeed "a good thing" that Marx secularized the concept of messianic time in the idea of a classless society. The problem, however, began when the social democrats interpreted this idea to an "ideal," which in neoKantian philosophy referred to an "infinite [unendlich] task." (Ibid., 401).

${ }^{122}$ Lukács, History and Class Consciousness, 89. 
this distorted view which presents the reification of time is the underlying premise that sustains our belief in progress; for it is because of our perception of time as a linear movement that we fail to understand it more profoundly, as that which goes beyond the realm of the profane, as that, which at every moment, can disrupt the dialectic of history, and finally usher the dawning of messianic time.

In addition to its forgetfulness of past injustices, the idea of continuity imposed by the historicist's view of history also denies a more profound understanding of our time as a certain "dislocation."123 Continuity, by its very form, is a "continual attempt to efface"124 this reality of dislocation, a constant denial of the fact that "the time is out of joint." 125 Unable to acknowledge the truth that "something in the present is not going well, [that] it is not going as it ought to go,"126 such continuity would therefore be a writing of history that no longer adheres to reality. And thus, this continuity, which constitutes the very form of what we call progress, fails to acknowledge that our time, as relation, is contrary to Dike (justice), and instead is a time of adikia (injustice). ${ }^{127}$

\footnotetext{
${ }^{123}$ Andrew Benjamin, Present Hope: Philosophy, Architecture, Judaism (New York: Routledge, 1997), 3.

${ }^{124}$ Ibid.

${ }^{125}$ This is a quote from Hamlet, act I, scene V. From Jacques Derrida, Specters of Marx: The State of the Debt, the Work of Mourning, and the New International, trans. Peggy Kamuf. (New York: Routledge, 1994), 3.

126 Ibid., 23.

${ }^{127}$ Derrida defines Dikè as justice related to a "joining, adjoining, adjustment, articulation of accord or harmony. . . . Diké harmoniously conjoins, in some way, the joining and the accord. Adikia to the contrary: it is at once what is disjointed, undone, twisted and out of line." (Derrida, Specters of Marx, 23).
} 


\section{Bibliography}

Adorno, Theodor. "Progress." In Critical Models: Interventions and Catchwords, 143-60. New York: Columbia University Press, 2005.

Agamben, Giorgio. "Language and History: Linguistic and Historical Categories in Benjamin's Thought." In Potentialities: Collected Essays in Philosophy, edited by Daniel Heller-Roazen, 48-61. Stanford: Stanford University Press, 1999.

Arendt, Hannah. "The Concept of History." In Between Past and Future: Eight Exercises in Political Thought. New York: Penguin Books, 1977.

—. The Origins of Totalitarianism. New York: Harcourt, Brace \& Company, 1951.

Beiner, Ronald. “Walter Benjamin's Philosophy of History.” Political Theory 12.3 (August 1984): 423-34. http://www.jstor.org/stable/191516.

Benjamin, Andrew. Present Hope: Philosophy, Architecture, Judaism. New York: Routledge, 1997.

Benjamin, Walter. The Arcades Project. Edited by Rolf Tiedemann. Translated by Howard Eiland and Kevin McLaughlin. Cambridge, MA: The Belknap Press, 1999.

—. "Eduard Fuchs: Collector and Historian." In One-Way Street and Other Writings, translated by Edmund Jephcott and Kingsley Shorter, 349-86. London: NLB, 1979.

. Illuminations. Edited by Hannah Arendt and Harry Zohn. New York: Schocken Books, 1969.

" "Konvolut N [On the Theory of Knowledge, Theory of Progress]." In The Arcades Project, 456-88.

—. "The Life of Students." In Selected Writings, vol. 1, 1913-1926, edited by Marcus Bullock and Michael W. Jennings, 37-47. Cambridge, MA: The Belknap Press, 1996.

- "One-way Street." In Reflections: Essays, Aphorisms, Autobiographical Writings, edited Peter Demetz, translated by Edmund Jephcott, 61-94. New York: Schocken Books, 1978.

. "Paralipomena to 'On the Concept of History."' In Selected Writings, vol. 4, 1938-1940, edited by Howard Eiland and Michael W. Jennings, translated by Edmund Jephcott et al., 301-11. Cambridge, MA: The Belknap Press, 2003.

—. "Paris, the Capital of the Nineteenth Century: Exposé of 1935." In The Arcades Project, 3-26. 
_ . "Theses on the Philosophy of History." In Illuminations, 253-64.

. "The Work of Art in the Age of Mechanical Reproduction." In Illuminations, $217-51$

Berlin, Isaiah. Karl Marx: His Life and Environment. 4th ed. Oxford: Oxford University Press, 1996.

Bewes, Timothy. Reification or the Anxiety of Late Capitalism. London: Verso, 2002.

Blanchot, Maurice. The Writing of the Disaster. Translated by Ann Smock. Lincoln: University of Nebraska Press, 1995.

Buck-Morss, Susan. The Dialectics of Seeing: Walter Benjamin and the Arcades Project. Cambridge, MA: MIT Press, 1993.

Collingwood, R. G. The Idea of History. Edited by Jan Van Der Dussen. Oxford: Oxford University Press, 1994.

Derrida, Jacques. Specters of Marx: The State of the Debt, the Work of Mourning, and the New International. Translated by Peggy Kamuf. New York: Routledge, 1994.

Despland, Michel. Kant on History and Religion. Montreal: McGill-Queen's University Press, 1973.

Engels, Frederick. Socialism: Utopian and Scientific. In Karl Marx and Frederick Engels: Selected Works in One Volume. New York: International Publishers, 1986.

Felman, Shoshana. “Benjamin's Silence.” Critical Inquiry 25. 2 (Winter, 1999): 201-34.

Gadamer, Hans-Georg. Truth and Method. 2nd ed. Translated by Joel Weinsheimer and Donald G. Marshall. New York: Continuum, 1999.

Hegel, G. W. F. Lectures on the Philosophy of World History. Translated by H. B. Nisbet. New York: Cambridge University Press, 1975.

Kant, Immanuel. "Idea for a Universal History from a Cosmopolitan Point of View." In Kant Selections, edited by Lewis White Beck. New York: Macmillan Publishing Co., 1998.

Kittsteiner, H. D., Jonathan Monroe, and Irving Wohlfarth. "Walter Benjamin's Historicism." New German Critique 39, Second Special Issue on Walter Benjamin (Autumn 1986): 179-215. http://www.jstor.org/stable/488125.

Lukács, George. History and Class Consciousness: Studies in Marxist Dialectics. Cambridge, MA: MIT Press, 1971. 
Nancy, Jean-Luc. "Finite History." In Birth to Presence, translated by Brian Holmes, 14366. California: Stanford University Press, 1993.

Plato. Phaedrus. Translated by Alexander Nehamas and Paul Woodruff. In Plato: Complete Works, edited by John M. Cooper. Indianapolis, IN: Hackett Publishing Co., Inc., 1997.

Rauch, Georg von. A History of Soviet Russia. 5th ed. Translated by Peter and Annette Jacobsohn. New York: Frederick A. Praeger Publishers, 1967.

Tiedemann, Rolf. "Historical Materialism or Political Messianism? An Interpretation of the Theses 'On the Concept of History."' In Benjamin: Philosophy, Aesthetics, History, edited by Gary Smith, 175-209. Chicago: University of Chicago Press, 1989. 